\title{
Säilörehun tuotantokustannusten hallinta
}

\author{
Sari Peltonen \\ ProAgria Keskusten Liitto, PL 251, 01301 Vantaa, sari.peltonen@proagria.fi
}

\section{Tiivistelmä}

Rehujen osuus maidontuotannon kustannuksista on noin kolmannes. Kotoisten rehujen osuus on $17 \%$ eli laskennallisesti noin 8 senttiä litralta. Se, millä hinnalla nurmirehut pystytään tuottamaan tilalla ja paljonko rehujen tarvetta pystytään täyttämään kotoisilla rehuilla, vaikuttaa siten merkittävästi maitolitran tuotantokustannuksiin.

Nurmirehujen tuotantokustannuksiin vaikuttavat eniten satotaso ja kiinteät kustannukset.

ProAgrian Lohkotietopankin tulokset osoittavat, että paras neljännes on onnistunut hyvän nurmisadon tuottamisessa ja kustannusten minimoimisessa, mutta haasteena on kustannuspaineisiin vastaaminen. Tulokset perustuvat kotoisten rehujen tuotantokustannuslaskelmiin noin 10000 hehtaarilta ja 350 maitotilalta vuosilta 2004-2008.

Säilörehun satotasoissa ei ole tapahtunut merkittävää parannusta viiden viimeisen vuoden aikana. Sen sijaan erot eri tilojen välillä ovat suuret. Keskimääräinen säilörehusato oli 5200 ry/ha vuonna 2008, kun se parhaimmalla neljänneksellä oli noin 6400 ry/ha ja heikommalla neljänneksellä 4000 ry/ha. Tuotantopanosten käytössä on jonkin verran eroja eri satoluokissa. Erityisesti lannoitus on selvästi suurempaa ja rikkakasvitorjunta yleisempää parhaimmassa neljänneksessä. Vaikka parhaimmalla neljänneksellä tuotantopanosten käyttö oli yleisempää, olivat niiden muuttuvat kustannukset kuitenkin $25 € /$ ha pienemmät kuin heikoimmassa neljänneksessä.

Keskimääräinen säilörehun tuotantokustannus oli 23 senttiä rehuyksiköltä vuonna 2008. Kustannukset kohosivat noin 3 senttiä vuoteen 2007 verrattuna. Suurimpana syynä tuotantokustannusten kasvamiseen olivat muut muuttuvat kustannuserät, joista polttoöljyn hinnan nousu oli merkittävin. Lannoituskustannusten nousuun vastattiin lannoitusta tarkentamalla ja valitsemalla edullisempia lannoitelajeja. Nurmen lannoitusmäärät vähenivät noin 10 \% vuonna 2008 aiempiin vuosiin verrattuna. Karjanlannan osuus säilörehun lannoituksesta on kasvanut vuosien mittaan.

ProAgrian Lohkotietopankin vuoden 2008 tulosten mukaan kannattavuudeltaan paras neljännes tuotti säilörehuyksikön 17,2 sentillä, kun heikoimmassa neljänneksessä tuotantokustannus oli lähes kaksinkertainen, 33,3 snt/ry. Parhaimmat tilat pystyivät siten täyttämään vuosittaisen lehmäkohtaisen nurmirehutarpeen 470 euroa halvemmalla kuin heikoimmat.

Nurmirehujen tuotannossa suurin kustannuserä on kiinteät kustannukset. Erityisesti konekustannus on huomattava ja vastaa noin kolmannesta nurmirehujen tuotantokustannuksesta. Kannattavuudeltaan paras neljännes on pystynyt karsimaan kustannuksia kaikissa menoerissä. Lohkotietopankin tulosten mukaan parhaimmalla neljänneksellä konekustannus oli noin $290 € /$ ha kun se heikoimmassa neljänneksessä oli $470 € /$ ha. Säilörehun tuotannossa konekustannukset ovat noin $150 € /$ ha korkeammat viljantuotantoon verrattuna.

Asiasanat: säilörehu, tuotantokustannus, kannattavuus, Lohkotietopankki 


\section{Johdanto}

Nurmirehujen tuotantoa, kuten muutakin kasvintuotantoa Suomessa rasittavat matala satotaso ja korkeat tuotantokustannukset. Maidontuotantotiloilla peltoviljelyyn panostaminen saattaa usein jäädä taka-alalle, lähinnä aika- ja resurssikysymysten vuoksi. Kotoisten nurmirehujen käyttö ruokinnassa vaikuttaa kuitenkin merkittävästi maidon tuotantokustannuksiin. Kotoisten rehujen osuutta kasvattamalla voidaan vähentää ostorehujen tarvetta. On kuitenkin tärkeää, millä hinnalla kotoisia nurmirehuja pystytään tuottamaan. Kotoisten rehujen osuus maidon tuotantokustannuksista on lähes viidennes eli noin $17 \%$.

Nurmirehujen tuotannon tehostamisessa keskeistä on satotasojen nostaminen. Nurmirehujen tuotantoon panostamista tulee tarkastella useamman vuoden tähtäimellä, ei vain käyttövuoden kustannuseränä. Hyviin satoihin johtavat toimenpiteet ovat nurmen huolellinen perustaminen, pellon hyvä peruskunto, säännöllinen kalkitus ja viljelykiertojen suunnittelu. Nurmille on järjestettävä hyvät kasvuolot, jotta se säilyttää kilpailukykynsä rikkakasveja vastaan. Onnistunut rikkakasvitorjunta nurmen perustamisvaiheessa luo pohjan hyvän nurmisadon tuottamiselle seuraavaksi 3-4 vuodeksi.

Nurmipinta-ala on järkevä mitoittaa rehutarpeen mukaan ja korjata mahdollisimman paljon rehua mahdollisimman läheltä tilakeskusta. Kun nurmirehua saadaan riittävästi entistä pienemmältä alalta, pienentää se yksikkökohtaisia kustannuksia, ja lisää samalla mahdollisuutta rehuviljan tai valkuaiskasvien viljelyyn muulla pinta-alalla. Toisaalta, jos nurmialaa ei ole riittävästi, on entistä tärkeämpää nostaa nurmisatoa, jotta säilörehuvajetta ei tarvitse täyttää kalliimmilla väkirehuilla.

Tuotannon tulosten laskenta, seuranta ja arviointi auttavat hahmottamaan tuotannon kannattavuuteen vaikuttavia tekijöitä ja mahdollisuuksia tuloksen parantamiseen omalla tilalla. Kun tiedetään nurmirehujen tuotannon kustannustaso, pystytään arvioimaan myös, millainen vaikutus sillä on maidon tuotantokustannuksiin ja mitä voidaan tehdä kustannusten hallitsemiseksi. Nurmirehujen tuotannon, käytännön tiloilla toteutuneiden tulosten tarkastelun avulla selvitettiin, millaisilla tuotantokustannuksilla maitotilat pystyvät nurmirehuja tuottamaan ja mistä mahdolliset erot johtuvat. Tavoitteena oli myös tarkastella eri tilojen tuotantokustannusrakennetta ja tuotantopanosten käyttöä nurmirehujen tuotannossa.

\section{Aineisto ja menetelmät}

Nurmirehujen tuotannon tuloksia tarkasteltiin ProAgrian Lohkotietopankkiaineistojen perusteella vuosilta 2004-2008. Tietoaineisto koostui noin 10000 hehtaarista ja 350 maidontuotantotilasta vuosittain. Lohkotietopankki on ProAgria Keskusten Liiton kehittämä tietojärjestelmä, jonne kootaan kasvintuotannon viljelytekniikka- ja satotietoja käytännön viljelyksiltä. Tietopankin tietosisältö koostuu lohkokohtaisista muistiinpanoista: viljelytiedoista, tuotantopanosten käyttötiedoista, satotiedoista, sekä tehdyistä tuotantokustannuslaskelmista.

Lohkotietopankin päätavoitteena on tuottaa tietoa kasvintuotannon kehittämiseen. Lohkoittain kirjatut viljelytoimenpiteet ja niiden tuloksena saavutettu sato tuottavat tietoa siihen, millaisella viljelytekniikalla ja millaisella tuotantopanosten käytöllä parhaimpaan, niin määrälliseen, laadulliseen kuin taloudelliseen tulokseen päästään. Tuloksia voidaan tarkastella monipuolisesti lohko-, kasvi-, lajiketai tuotekohtaisesti eriteltynä. Näin saadaan tietoa tai voidaan hakea syitä onnistumisille tai mahdollisille epäonnistumisille kun vertaillaan hyvään ja huonoon satotulokseen johtaneiden lohkojen viljelytietoja keskenään. Yhdistämällä tietopankin tiedot eri tiloilta saadaan tilan toiminnan tarkasteluun ja kehittämistavoitteisiin aluekohtaisia ja valtakunnallisia vertailu- ja kehittämistietoja.

ProViljelys on ProAgria Keskusten tarjoama kasvintuotannon kehittämispalvelu, jossa suunnitellaan kasvintuotannon toteutus tilalla viljelyteknisesti ja taloudellisesti parhaalla tavalla. Lisäksi palvelulla tarkennetaan tuotantopanosten käyttöä ja toimenpiteiden oikeaa ajoitusta kasvukauden aikaisin tilakäynnein. Satokauden päätyttyä selvitetään kasvintuotannon viljelytekninen onnistuminen ja taloudellinen tulos sekä määritetään kehittämiskohteet ja tavoitteet seuraavalle vuodelle. Käytössä ovat Lohkotietopankin vertailuraportit ja sen tarkempaan tilakohtaiseen tuloraportointiin kehitetty Tilakunto-verkkopalvelu (www.proagria.fi/verkkopalvelut).

\section{Tulokset ja tulosten tarkastelu}

Nurmirehusadon määrä oli tärkeä tekijä tuotantokustannusten hallinnassa ProAgrian Lohkotietopankin tietojen mukaan. Lisäksi kiinteät kustannukset, erityisesti konekustannukset vaikuttivat oleellisesti 
tuotantokustannuksiin. Säilörehun sato vaihtelee paljon vuosittain, alueittain ja tilojen välillä. Suurin vaihtelu on kuitenkin tilojen välillä. Vuoden 2008 tuloksissa säilörehusato vaihteli yli 2000 rehuyksikköä hehtaarilta parhaimman ja heikomman neljänneksen välillä (Kuva 1). Tuotantokustannuksissa oli vastaavasti eroa yli 16 senttiä rehuyksikköä kohden. Se tarkoittaa ruokintakustannuksina noin 470 euron eroa lehmää kohden vuodessa.

Nurmisadon määrään vaikuttaa oleellisesti se, kuinka monta satoa nurmesta tavoitellaan. Ensimmäinen sato on tyypillisesti runsain ja siihen olisikin panostettava eniten. Jos nurmipinta-alaa on paljon, voi tietyissä tapauksissa yhden sadon korjaaminen olla riittävä. Jälkisatoja korjatessa on huomioitava, että pienten rehuyksikkömäärien korjaaminen voi tulla hyvinkin kalliiksi. Lohkotietopankin tulosten mukaan kolmannen sadon määrä jäi keskimäärin alle 1000 ry/ha. Jos jälkisatojen korjuu on nurmirehujen riittävyyden kannalta merkittävä, on myös niihin panostettava. Riittävä lannoitus sekä sadetus - mikäli sellainen mahdollisuus on - takaavat hyvän jälkikasvun.

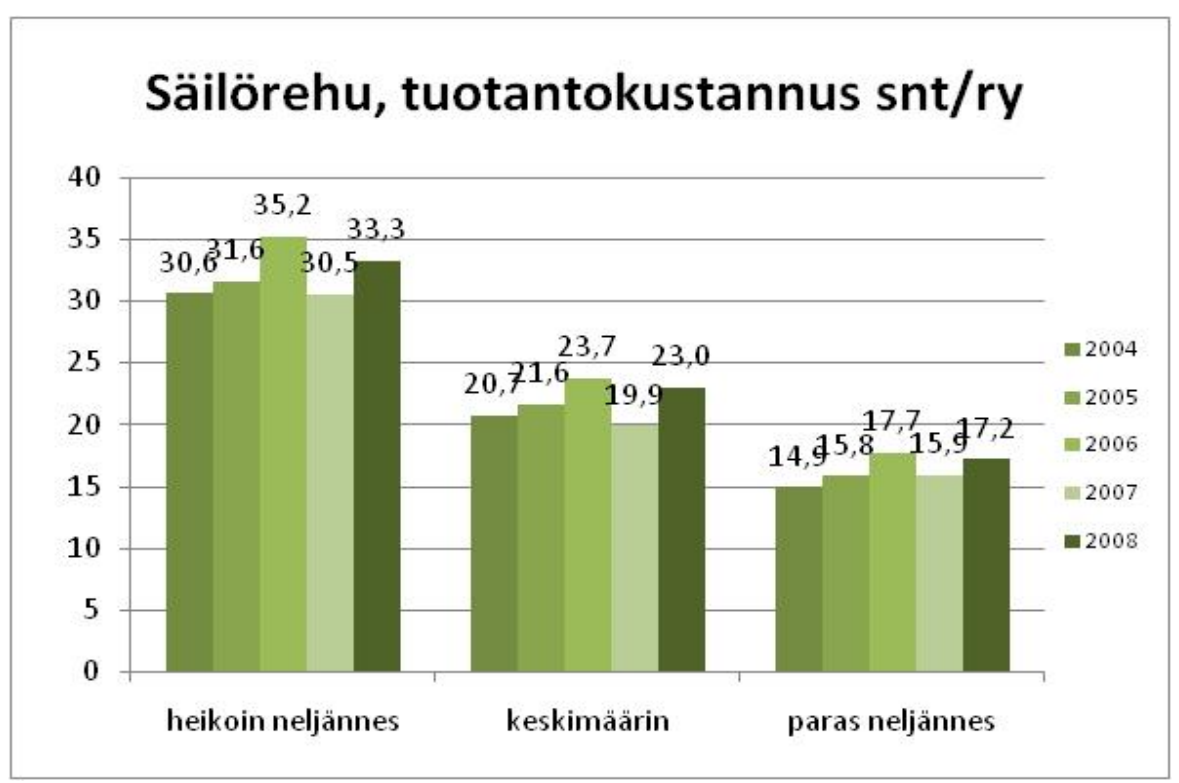

Kuva. 1. Säilörehun tuotantokustannus on ollut maidontuotantotiloilla keskimäärin 20-23 snt/ry vuosina 20042008. Tuotantokustannuksissa on kuitenkin suuri ero heikomman ja parhaimman neljänneksen välillä. Lähde: ProAgria Lohkotietopankki.

On kuitenkin huomioitava, että satoa ei tule nostaa laadun kustannuksella. Nurmen korjuuajankohtaa säätelee D-arvo, jonka optimi on 69-71 \%. Korjuuta ei kannata myöhästyttää paremman sadon toivossa, koska silloin rehun laatua ja sulavuutta kuvaava D-arvo saattaa laskea liikaa. Ei myöskään riitä, että nurmisato saadaan hyvälaatuisena korjattua, vaan että se tulee saada hyvälaatuisena ruokintaan asti. Hyväkin nurmisato voidaan pilata tinkimällä väärässä paikassa eli rehun säilönnässä. Hyvän nurmisadon määrän varmistaa huolellinen säilöntä, johon kuuluu riittävä säilöntäaineen käyttö ja tiivistäminen sekä perusteellinen auman suojaus.

Karjanlannan ravinteiden osuus säilörehun lannoituksesta on kasvanut vuosien mittaan. Kehitys on hyvä sekä kotieläintilan parempien ravinnekiertojen että kustannusten hallinnan kannalta. Kotieläintiloilla, erityisesti niillä, joilla on suuria ravinneylijäämiä, tulisi kiinnittää huomiota erityisesti ostoravinnepanosten tarpeellisuuteen. Vuoden 2008 tuloksissa säilörehun lannoitustasot olivat alentuneet noin $10 \%$ johtuen lannoituskustannusten voimakkaasta noususta.

Eri säilörehukorjuutyyppien välillä ei ollut suuria eroja kustannuksissa. Esikuivattu säilörehu oli yleisin korjuutapa, ja myös sen satotaso oli korkeampi ja tuotantokustannukset pienemmät kuin tuoresäilörehulla tai paalisäilörehulla. Suurimmat erot säilörehun kustannusrakenteessa ovat eri tilojen välillä huolimatta niiden käyttämistä koneketjuista.

Nurmirehujen tuotannossa suurin kustannuserä on kiinteät kustannukset. Erityisesti konekustannus on huomattava kustannuserä ja se vastaa noin $30 \%$ nurmirehujen tuotantokustannuksesta. Nurmentuotannossa konekaluston määrä voi kasvaa hyvin suureksi, erityisesti jos tilalla on myös viljankylvöön ja -korjuuseen sekä lannanlevitykseen kuuluva kalusto. Säilörehun tuotannossa konekustannukset ovat noin $150 € /$ ha korkeammat viljantuotantoon verrattuna. Erot eri tilojen välillä voivat kui- 
tenkin olla suuria. Lohkotietopankin tulosten mukaan parhaimmalla neljänneksellä konekustannus oli noin 290 €/ha kun se heikoimmassa neljänneksessä oli 440 €/ha. Konekustannusten paremmassa hallinnassa tulee huomio kiinnittää konekannan käytön tehostamisen mahdollisuuksiin, urakoinnin hyödyntämiseen tai yhteishankintoihin.

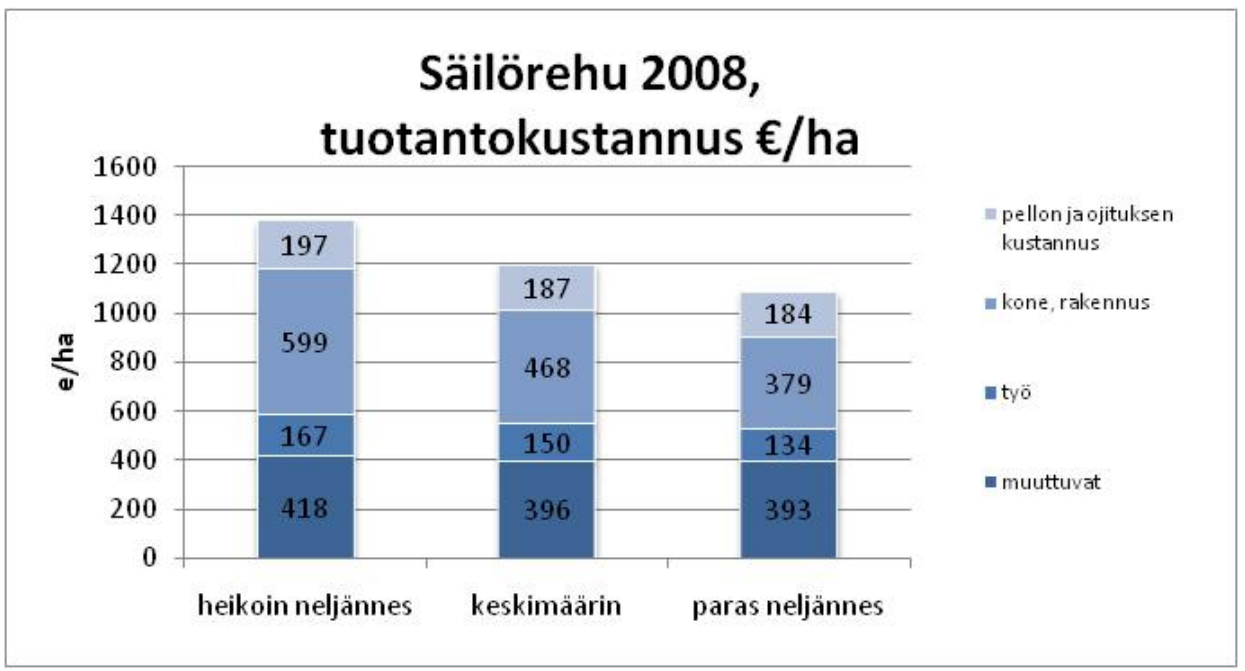

Kuva. 2. Säilörehun tuotantokustannuksissa suurimman kustannuserän muodostavat kiinteät kustannukset, joista konekustannus on merkittävin. Kannattavuudeltaan paras neljännes on pystynyt karsimaan kustannuksia kaikissa menoerissä. Lähde: ProAgria Lohkotietopankki.

\section{Johtopäätökset}

Nurmirehujen tuotannon tehostamisessa keskeistä on satotason nostaminen, jonka lähtökohtana on nurmen huolellinen perustaminen ja viljelyn keskittäminen peruskunnoltaan hyville pelloille. Satotason nostaminen yli 6000 ry/ha pienentää yksikkökohtaisia tuotantokustannuksia merkittävästi. Kotieläintiloilla olisi näin mahdollista parantaa nurmirehujen tuottavuutta merkittävästi, jolloin rehuntuotantoon varattua pinta-alaa voisi ohjata rehuviljan tai valkuaiskasvien viljelyyn ja siten parantaa ruokinnan valkuaisomavaraisuutta.

Kustannusten hallinnassa tärkeää on tuotantokustannusrakenteen tarkastelu ja tilalle sopivien vaihtoehtojen löytäminen tuotannon kiinteiden kustannusten pienentämisessä. Konekustannusten paremmassa hallinnassa tulee huomio kiinnittää konekannan käytön tehostamisen mahdollisuuksiin, urakoinnin hyödyntämiseen tai yhteishankintoihin.

Tuotannon tulosten seuranta ja arviointi tilakohtaisesti ovat avainasemassa, kun haetaan mahdollisuuksia tilatason kannattavuuden parantamiseen. Tulosten vertaaminen auttaa löytämään tuotannon kehityskohdat. Vuosittainen tulosten seuranta taas paljastaa tulosten kehityssuunnan ja antaa merkkejä siitä, milloin ja mihin pitää reagoida.

ProViljelys kehittämisryhmien toiminnassa on korostunut, miten tavoitteellisen suunnittelun, kasvukauden aikaisin mittauksin sekä tulosten seurannan avulla on mahdollista löytää tuotannon kehittämiskohteet ja näin pienentää viljelyn epäonnistumisen riskejä. ProViljelys kehitysryhmissä panostetaan kasvintuotannon tuotantovarmuuden ja sadon laadun parantamiseen asiakkaan tai tuotantoeläinten ruokinnallisten vaatimusten mukaisesti sekä kokoamaan tietoa tuloksellisen kasvin- ja rehuntuotannon menetelmistä Lohkotietopankkiin. Vertailutietojen käyttöön on myös kehitetty Tilakuntoverkkopalvelu (www.proagria.fi/verkkopalvelut).

\section{Kirjallisuus}

Heikkinen, A-M., Pakarinen, K., Punkki, P., Rossi, A., Puurunen, T., Sairanen, A., Virkajärvi, P. (toim.) 2007. Pohjois-Savon nurmiopas. Pelto Tuottamaan - Pohjois-Savoon valtakunnan parhaat nurmet -hanke. $50 \mathrm{~s}$.

Karttunen, J., Peltonen, M. \& Pentti, S. 2004. Säilörehun korjuuketjun suunnittelu. Rehuketjujen kustannukset ja pullonkaulojen minimointi. Työtehoseuran maataloustiedote (568) 5/ 2004. 8 s.

Virtanen, H. \& Nousiainen, J. 2005. Nitrogen and phosphorus balances on Finnish dairy farms Agricultural and Food Science 14: 166-180. 